\title{
Article \\ Children and Trauma: Unexpected Resistance and Justice in Film and Drawings
}

\author{
Cheri M. Robinson \\ Department of Spanish \& Portuguese, University of California, Los Angeles, CA 90095-1532, USA; \\ cherirob7@g.ucla.edu
}

Received: 22 November 2017; Accepted: 14 February 2018; Published: 26 February 2018

\begin{abstract}
This transnational study examines representations of and by children-whether literal wounds, psychological ones, or wounds transmitted through drawings-that manifest their capacity for unexpected resistance and justice. It considers the Mexican-American director Guillermo del Toro's use of hauntings and wounds to explore violence during the 1936-1939 Spanish Civil War in the film El espinazo del diablo [The Devil's Backbone] (2001) and its intersections on strategic and theoretical levels with the traumatic in archival children's drawings produced during the 1976-1983 Argentine military dictatorship. The drawings illustrate the violence perpetrated against the child artists' families and were produced in exile for the human rights organization COSOFAM. Utilizing diverse theories from film and trauma studies, among others, this article analyzes key scenes in El espinazo exhibiting commonalities with representations of traumatic violence in the children's drawings, revealing that, in fiction and in fact, a strategic "showing" of the traumatic wound is designed to remind others of the imperative to intervene in situations of extreme violence, to appeal to/for justice, and to effectively testify from the inside.
\end{abstract}

Keywords: film; archival drawings; human rights; representations of traumatic violence; children; transnational

This transnational study analyzes hauntings and wounds in the Mexican-American director Guillermo del Toro's fictional interpretation of violence during the Spanish Civil War (1936-1939) in the film El espinazo del diablo [The Devil's Backbone] (2001) and its intersections with representations of traumatic violence during the Argentine military dictatorship (1976-1983) in archival children's drawings. ${ }^{1}$ The archival drawings illustrate violence-armed guards, prison bars and cells, captives (almost exclusively women and children)—perpetrated against the child artists' families. ${ }^{2}$ Produced in exile in the Netherlands for the human rights organization COSOFAM or the Comision de Solidaridad con Familiares de Desaparecidos en Argentina [Commission of Solidarity with Family Members of those Disappeared in Argentina], the drawings in my view represent the traumatic highlighting of state violence and a cry for justice, which I posit intersects with del Toro's representational strategies. The artistic representations in both instances work through a "showing" of the wound, an appeal to/for

1 IMPORTANT NOTE: Pictures of the archival drawings were obtained with the permission of the Archivo Nacional de la Memoria [National Archive of Memory] in Argentina and cannot be reproduced for monetary gain or without authorization. I have not included the drawings within the text due to restrictions regarding their dissemination.

2 According to the Catálogo de Fondos Escritos/Audiovisuales/Fotográficos [Catalogue of Written/ Audiovisual/Photographic Collections] (Alicia Raquel Puchulu de Drangosch Archive 2014), Alicia Raquel Puchulu de Drangosch founded and was president of COSOFAM in the Netherlands during the Argentine military dictatorship. She was forced to flee Argentina to ensure her and her family's safety. I discovered the children's drawings/postcards in her archive, part of a collection donated in 2014 by her daughters to the Archivo Nacional de la Memoria in Buenos Aires, thanks to the Ben and Rue Pine travel grant (2015). 
justice, and potentially catharsis. ${ }^{3}$ At least two films connected to del Toro, El espinazo del diablo [The Devil's Backbone] (2001) and El orfanato [The Orphanage] (2007), employ phantoms and children's drawings to "show" hidden violence and unresolved injustices. ${ }^{4}$ This study refers to the wounded child phantom Santi and the orphan Jaime's drawing of his murdered body in El espinazo and their potential intersections with the archival drawings on strategic and theoretical levels. ${ }^{5}$ Otherwise stated, drawings in both instances employ similar strategies and functions to unveil violence and seek justice, demonstrating children's agency in the process.

These representations of and by children-whether literal wounds, psychological ones, or wounds transmitted through drawings-manifest children's capacity for unexpected resistance and justice. In both del Toro's fictional interpretation and the Argentine/Dutch human rights campaign-a campaign in which children were simply instructed, "Hagan dibujos sobre la situación en Argentina" ['Draw about the situation in Argentina'] (Moyano 2016) — children testify of violence. ${ }^{6}$ Although the child artists in the Netherlands were asked to create drawings about the situation in Argentina-per my correspondence with E. Moyano, the granddaughter of the founder of COSOFAM and one of the child artists, - they were not told specifically what to draw, just as the child artist in El espinazo also chose what he would represent. ${ }^{7}$ As such, their representational choices are ones based on free will and, in this article, choice is tied to agency. The child artists, though very young, possessed knowledge of (had witnessed) the violence that forced their families to flee Argentina; the orphans in El espinazo also developed a painful awareness of the violence tearing their world apart as they witnessed it and were wounded by it. This traumatic knowledge positions the children in both El espinazo and the Netherlands as agents capable of choosing based upon a full knowledge of the traumatic.

The archival drawings were imprinted on postcards that were mailed by COSOFAM and others in the Netherlands to the President of the Supreme Court of Justice, D. Adolfo Gabrielli, at the Palace of Justice in the Argentine Federal Capital and possibly to other unknown recipients. According to A. Calvo, an employee at the Archivo Nacional de la Memoria, these kinds of postcards were commonly produced to be sent to judges, military personnel, priests, or Argentine authority figures, among others, by parties sympathetic to human rights work and/or overtly against the military dictatorship (Calvo 2016). ${ }^{8}$ Calvo remarked that campaigns of this sort were used to pressure authorities from abroad, and it is possible that other sets of postcards were mailed from the Netherlands (Calvo 2016). Moyano was eight or nine years old when the drawings were created and was aware they were to be made into postcards, although she did not know if they were part of fundraising activities for the organization or if they were mailed to other organizations like the United Nations (Moyano 2016). According to Calvo and the information on the postcards, it is clear they were mailed to a judge. Therefore, the archival drawings are categorized as (artistic publicity) "exposing" the dictatorship, which situates them as unique tools demonstrating the violation of human rights through children's personal experiences with state violence. When viewed as tools that expose concealed violence, they then serve the same function as the diegetic drawings in El espinazo. It is pertinent to mention that,

3 My initial research findings on the comparative study of children's drawings in del Toro's films and those from the archive in Argentina were first presented at the ACLA Annual Meeting at Harvard University in 2016. Since then, I have altered and expanded upon my initial conclusions based on new information.

4 This theme of the traumatic past/phantoms haunting the present is represented in El orfanato (2007), directed by J.A. Bayona with del Toro as an executive producer.

5 I recognize that many scholars might disagree with my decision to juxtapose representational strategies and purposes of a fictional interpretation with archival drawings, and I want to emphasize that my intention is to place them in dialogue with each other, not to suggest that the Spanish Civil War and the Argentine military dictatorship were the same. They are distinct historical events, but that does not mean reconstructions of violence pertaining to either period cannot pursue similar strategies or purposes.

6 Translations from Spanish to English are mine; please note that I have attempted to maintain the original meanings instead of translating word for word.

7 Names of personal correspondents have been shortened for privacy.

8 Information was also obtained via email from I. Suarez. "Archivo nacional de la memoria-Cartas postales de COSOFAM." Email message to author, 27 May and 14 September 2016. 
although the grounding of human rights on one's humanity is a common assumption, it has failed to hold true in many instances initially discussed by theorists such as Hannah Arendt (Arendt 1958, pp. 291-92) who claimed that the rights of man, with the growing problem of statelessness, were found to be tied to established governments, not to the individual.

The archival drawings, when seen as a response to a reorganizational process in Argentina tied to annihilation as a tool of social engineering (Feierstein 2014), become more than isolated incidents of violence, more than decontextualized images, or simple revelations. They instead take on additional meaning as a haunting of the disappeared victim — by revealing concealed violence and calling for an outside recognition of injustice (while abuses were still occurring in Argentina, prior to full-exposure) in much the same way that the murdered child Santi becomes visible through a drawing and his haunting of the orphanage (while violence continues to unfold, prior to the murderer's exposure). The drawings demonstrate the resilience of the "memory" of those disappeared and appropriated, a memory that continues to resist discourses of exclusion, as the past continually revisits (haunts) the present each time the drawings are viewed.

Is a drawing, much like a photograph or the image of Santi's wounded body (in Jaime's drawing and as a phantom), still powerful whether decontextualized or recontextualized? In her essay on "Cuerpos políticos/Body Politics," Taylor (2009) references Fernando Gutiérrez's photograph "Cosas del río" ['River Things'], her friend (viewing the photo) Mario Bronfman's connection to exile, and the photograph's decontextualized images that were nonetheless powerful in their symbolism:

Photography, the art of de- and re-contextualizing, can isolate and freeze the moment, much in the way that violence ruptures our present from our past and freezes time in a simple before/after ... The violent separation of each object, bracketed off from the rest, also invokes the pain and isolation of exile, the life lived out of place. The photograph unsettles-showing simultaneously too little and too much. (Taylor 2009, p. 22).

The children's drawings, much the same as the photographs and the image of the wounded child, also show too little and too much, but the power of these images remains undeniable. They evoke an emotional response even when standing alone, and emotion draws the viewer in - counteracting a potentially disinterested or distant stance. They serve as a silent witness of the child artists' traumatic pasts and validate pain - potentially with or without a narrative attached to them. However, as with the following analysis of del Toro's film and the situation of the traumatic within a narrative of sense (narrative memory + the restoration of sense), I have chosen to contextualize the drawings separately from the film by providing information obtained from the Archive and personal correspondence.

In lieu of fictional works distorting or distracting from the actual act of bearing witness to violence, filmic fiction can serve a purpose parallel to that of artistic representation, whether utilized as an appeal to/for justice (through the exposure of acts of violence) or as catharsis (a means of "working-through" the traumas of one's past or present). Concerning catharsis, C. Gardner, an employee at South Coast Hospice in Oregon, informed me that art is often used as therapy for children (Gardner 2017). She indicated that their former Light House Program, a support/grief group whose purpose was to assist children who had lost a loved one or experienced a traumatic event that they were unable to adequately describe in words, employed art, collages, crafts, and games (Gardner 2017). In the case of the Light House Program, as with the diegetic drawing, which Jaime creates after witnessing Santi's murder, art may be viewed as a purposeful return to the place of trauma to aid healing or as a "coming to terms" for a grieving or traumatized individual.

\section{Representations of the Traumatic}

Carolina Rocha and Georgia Seminet group El espinazo del diablo within a category of films that present "the trend depicting the war years and the Franco dictatorship" from the perspective of children and adolescents: "First, preadolescent children are much more frequently cast in filmic narratives constructed on historical memory and trauma" (Rocha and Seminet 2012, p. 4). They 
describe the film as follows: "Characterized as a transnational film par excellence, El espinazo takes place in an orphanage that acts as a 'microcosm for the conflict taking place outside'" (Rocha and Seminet 2012, p. 11). From this standpoint, the traumatic events within the orphanage-tensions between the teachers and young boys (supporters or children of Republicans) \& Jacinto, a former orphan who turns against the orphanage for greed, and his thuggish accomplices (potentially the Nationalist band, potentially simple profiteers)—mirror the conflict without, the struggle between the Republicans (loyal to the Second Republic) and the Nationalists (led by General Francisco Franco) (Lázaro-Reboll 2007). This study focuses on the war within and the wounds resulting from the betrayals and murders committed by Jacinto.

The viewer first witnesses the body of the wounded child in the initial sequence. The sequence is a series of five shots, connected by the voice-over of Dr. Casares and a dissolve from the fourth to the fifth shot, exploring the meaning of a phantom:

DR. CASARES. ¿Qué es un fantasma? Un evento terrible condenado a repetirse una y otra vez. Un instante de dolor, quizás. Algo muerto que parece por momentos vivo aún. Un sentimiento suspendido en el tiempo, como una fotografía borrosa, como un insecto atrapado en ámbar.

DR. CASARES. What is a phantom? A terrible event condemned to repeat itself time after time. An instant of pain, perhaps. Something dead that at times seems still alive. A sentiment suspended in time, like a blurred photograph, like an insect trapped in amber. (El espinazo del diablo [The Devil's Backbone] 2001).

The voice-over is repeated at the end of the film with an additional line revealing the Doctor's own connection to phantoms. The film's narration, mostly linear and chronological except for several flashbacks, is united by the repetition of the beginning voice-over, paired with a new set of shots, at the end. The initial establishing sequence begins with a slow movement towards a darkened doorway ["¿Qué es un fantasma? Un evento terrible condenado a repetirse una y otra vez."], then cuts [sound of the cargo doors opening] to the underside of a plane as the cargo doors open and a bomb drops into a rain-filled sky illuminated by various explosions and fires on the ground. The shot ends with the closing of the cargo doors, and the next one starts with the image of a wounded child (later identified as Santi) lying on the ground ["Un instante de dolor, quizás."]. His head has a large gash that is bleeding out onto the ground as another boy (later revealed to be Jaime) touches the wound, bloodying his own fingers and face in the process, and cries ["Algo muerto que parece por momentos vivo aún."]. The fourth shot is of a murky body of water with an initially unknown object that appears to be sinking ["Un sentimiento suspendido en el tiempo,"]. A boy's face is finally visible ["como una fotografía borrosa,"], his body descending deeper into the water, while the camera moves up and outside of the water to show the older boy from the third shot, still crying, as he gazes into the body of water, now visibly a cistern ["como un insecto atrapado en ámbar."]. The fourth shot is connected to the fifth, final shot as the cistern scene dissolves into another murky fluid with unrecognizable objects floating in it. These objects are eventually identified as fetuses with exposed spinal cords or spina bifida, an allusion to the devil's backbone from which the film derives its name.

This initial sequence firmly links El espinazo to the imagery of trauma: (1) The darkened doorway or entrance into the traumatic, the unknown, and death; (2) the bomb or harbinger of death (condemned to repeat itself); (3) the moment of trauma or the wound of the child; (4) the place of trauma or the scene of the crime and its concealment; and (5) the open wounds on the bodies of the fetuses. With these images and Dr. Casares's question/response in mind, the viewer delves into del Toro's traumatic world as the images, pieces to a larger puzzle, are explored and slowly fitted together to form a more cogent picture of the moment of trauma. 
Scholar and trauma theorist Cathy Caruth describes trauma as an unassimilated event that extends beyond a simple violent act: ${ }^{9}$

Just as Tancred does not hear the voice of Clorinda until the second wounding, so trauma is not locatable in the simple violent or original event in an individual's past, but rather in the way that its very unassimilated nature-the way it was precisely not known in the first instance-returns to haunt the survivor later on. (Caruth 1996, p. 4).

The wound and the voice that cries out from it are tied to the belatedness of trauma, its unassimilated nature, and its being not known at the moment of wounding; for these reasons, the "missed" trauma may return to haunt those who survive the initial wounding (p. 4). El espinazo revisits a past violence through the phantom child's return to (his haunting of) the place of trauma (a concealed murder). The use of wounded phantoms in the film is literally a return to the haunting of trauma in trauma studies. The traumatic is given materiality in the frightful appearance of the wounded phantom child Santi while the abject that produces repulsion is also unexpectedly re-appropriated as both a warning of future violence and a cry for justice for past violence. Through traumatic imagery, Santi and the other orphans are converted into sites of traumatic memory (symbolically) and (literal agents of) justice, one founded in natural law and the supernatural-both of which must serve the victims in the absence of positive laws and guardians to protect them.

Santi, although a phantom seen by a child, appears as more than an inner fantasy; he also bears the marks of an outer violence that takes on physicality in his labored breathing and profusely bleeding head wound. Santi's pain circulates through an aching of the senses and a presentation of grotesque violence- a brutality that causes the spectator to cringe. The use of affect is striking and necessary, a shock linked to sense and justice. This justice will be brought to Santi through the intercession of the main protagonist, Carlos, who will witness and know the site of the unknown trauma-unassimilated but not unwitnessed by Jaime, an older boy at the orphanage present at the time of Santi's murder, who initially remains silent yet draws the murdered boy with a head gash in his sketchbook. Returning to the "originary meaning of trauma" as corporeal (Caruth 1996, p. 3), the haunting of the traumatic becomes more than a wounded mind; it is also externalized in a boy and his wounded, slain body or other mutilated and murdered bodies-all peopling the landscape of Civil War Spain. To "know" the trauma of the phantom child, of the children and teachers killed in the orphanage, Carlos and the orphans must recognize the significance of the open wound and return to the site of violence to bear witness and bring justice. This process of recognition and return works to reestablish equilibrium and sense and to reincorporate traumatic memory back into narrative memory (Van der Kolk and van der Hart 1995, pp. 158-82) by knowing the belatedness inherent in the original moment of trauma.

The wound acts as a testimony of unresolved violence in the manners in which it is presented to Carlos and the viewer. Scholar Adriana Bergero argues that the abject circulates, attempting to diminish the distance between it and the living: "En la escena gótica-film de horror y para el estupor de los vivos, el monstruo abyecto se constituye como un otro inconveniente que circula ansioso por acercar distancias con los vivos" ['In the gothic scene/horror film and to the amazement of the living, the abject monster constitutes itself as an inconvenient other that circulates, anxious to move closer to the living'] (Bergero 2010, p. 443). Throughout the film, the attempt to establish contact and diminish distance occurs first on Santi's part and finally on the part of Carlos. There is a gradual movement from repulsion to solidarity: from sight to touch and from aversion to empathy and understanding.

Santi first appears to Carlos in the daylight. He is viewed from a distance, and the contact is based on sight alone. The viewer, but not Carlos, is privy to a shot of Santi's face through a dirty window.

9 Caruth appropriates the symbols of the wound and the voice from Freud's analysis of a story, recounted by Tasso in the epic Gerusalemme Liberata [Jerusalem Delivered] (1581), about the knight Tancred who accidentally wounds his beloved Clorinda (Caruth 1996, p. 2). 
Insects are flying around him, and he appears destitute. Carlos is still unaware that the boy he saw is a phantom, but the viewer is now cognizant of the figure's abnormal appearance. Santi's second contact with Carlos is through Carlos's physical connection with his former sleeping area (bed number 12); he responds with a murmur when his name is spoken aloud (sound). ${ }^{10}$ Carlos sees Santi's shadow again, but this time the shadow reaches out to him as Carlos asks him who he is. Santi proceeds to knock over the water pitcher at the end of the bed, and as the water spills onto the floor (perhaps an allusion to the cistern) his retreating footprints are visible on the wet floor. Santi's attempt to establish contact is again interrupted by the approach of the other orphans.

In the kitchen scene where Carlos and Jaime are filling their water pitchers, Santi approaches Carlos again with a whisper of his name (sound). As he descends the stairs into the cistern room, a shadow runs by, and there is a brief close-up shot of Santi's wounded and decaying face. Santi appears behind Carlos; as he touches Carlos's arm, he screams and disappears (touch and sound). Santi has crossed the barrier; he has transitioned from sight to sound to touch. He also leaves a trace of the blood from his wound in the air, blood that is touched and rubbed between Carlos's fingers, testing its materiality. A voice-off of Santi is heard, "Muchos van a morir" ['Many are going to die']. He sounds as if he were struggling for breath, but his words are still perceived as a threat, not yet a warning. When Carlos again flees, Santi attempts to follow him. He ascends the stairs while Carlos is struggling to squeeze outside of the locked door. Santi may have eliminated the physical distance separating him from Carlos in the cistern room, but he is still far from effectively communicating. His abject appearance repulses instead of inspiring pity. The absence of empathy and sense is firmly in place.

Sociologist Gabriel Gatti speaks of the forced disappearances of people as catastrophes that occurred in the terrain of sense and especially affected identity and language (Gatti 2011, p. 85). While the archival drawings certainly fit within the category of "catastrophe" as they display violence enacted against families that resulted in the forced disappearances of loved ones (inexpressible acts affecting familial ties), Santi's trauma is not necessarily in the traditional arena of the disappeared, in the Southern Cone sense-although he is believed missing or considered a runaway before his murder is discovered. However, it does share some common characteristics when viewed through the lens of the more universal description of a desaparecido ['a forcibly disappeared person'] (Gatti 2011, p. 228). Essentially, el desaparecido modélico [the prototypical desaparecido] (again, in the Southern Cone sense) has evolved into el desaparecido transnacional ['the transnational desaparecido'] which in turn has been re-appropriated in el desaparecido local ['the local desaparecido'] (p. 221). The archival drawings fall within the concept of el desaparecido modélico; whereas, in Santi's case, the re-appropriation of el desaparecido local occurs in the figure of the wounded orphan-a defenseless child made more vulnerable by his exposure to the violence of civil war and those like Jacinto who take advantage of the dismantling of protective structures. Where the archival drawings and filmic representations of the traumatic both meet (in a contemporary context) is in the concept of el desaparecido transnacional, elaborated in international human rights legislation in organizations like the United Nations, to which COSOFAM was potentially appealing, and other human rights groups whose description of the concept later expands to include marginalized/socially invisible persons like the boys in the orphanage. ${ }^{11}$

Gatti's elaboration on the evolution of the term desaparecido also includes a restitution of sense to an act, desaparición forzada ['forced disappearance'], that dismantles the links of identity, family, community, and language (p. 85). The act represents the absence of sense. I propose that del Toro utilizes representational strategies (hauntings and open wounds on the bodies of orphans) and the language of affect—or more specifically the emotions of horror, fear, and pain, along with the pursuit of justice-to restore sense to the broken body of a child. By considering the language of affect as a restoration of sense in the film, I believe Gatti's proposition that one's reaction to absence, emptiness,

10 Carlos pronounces the name "Santi," carved on the wall by the bed.

11 One example is the International Convention for the Protection of All Persons from Enforced Disappearance (December 2006). 
and a lack of sense is "to fill it with sense" (llenarlo de sentido) provides an intriguing rationale for the use of horror or the gothic to revisit the traumatic past (p. 88).

The term desaparecido/a has evolved into a referent for those terrible, exceptional situations that pose problems of referentiality: "En fin, diría que hoy el desaparecido cataliza las hablas de la lengua de lo ausente del sentido" ['In short, I would say that today the desaparecido, or figure of the forcibly disappeared person, catalyzes the speech of the language of the absence of sense'] (emphasis Gatti's) (Gatti 2011, p. 229). Gatti describes the term's broad applicability as if it were a substitute for that which has no name or place, "Y en la medida que el desaparecido se eleva a ese lugar, el de referencia, metáfora, concepto, el lenguaje que fue útil para hablarlo se convierte también en el lenguaje de esas cosas sin nombre ni lugar" ['And to the extent that the desaparecido is raised to that place, that of reference, metaphor, concept, the language that was useful to speak of it is also converted into the language of those things without name or place'] (emphasis Gatti's, p. 229). In El espinazo's exhibition of the child's wounded body, the intolerable image fills in as a metaphor or visual language to reveal an environment defined by a void of sense and empathy that creates a fertile ground for the propagation of violence and, in the displaying of the intolerable image, for the filling of this vacuum with an overabundance of sense and emotion. In the orphanage, the ties linking the children to their families and communities have been broken by war and death; they are fragments of a larger whole that has been dismantled by the violence of civil war. In such an environment, full of pain, the phantom child returns to remind Carlos that his wounds are crying out. Santi's body serves as a testimony to the materiality of the trauma he suffered, and his wounds shock the desensitized viewer into feeling.

The child's battered body is visually intolerable in its all "too real" depiction of reality. I propose that the graphic nature of the wounded body falls under Jacques Ranciere's analysis of the "shift from the intolerable in the image to the intolerability of the image" (Ranciere 2009, pp. 83-84). Although the wounded orphans and Santi's abject appearance provoke the aversion of the viewer's gaze, just as they initially evoke Carlos's fear and desire to flee, the purpose of displaying such brutality is precisely to remove the traumatic event from its state of isolation and to restore sense to the absence of sense. The intolerable image is contextualized; it serves a purpose. The reincorporation of traumatic histories and the restoration of sense occur in the situating of the intolerable image within the sequence of events that made it intolerable, not in its situation as an isolated event that would possibly lead to its intolerability. The intolerability of the image is displaced by "the construction of the victim as an element in a certain distribution of the visible. An image never stands alone" (Ranciere 2009, p. 99). The abject appearance of Santi's wounded body is intolerable, as are the images of violence in the archival drawings created by children, but the open wound or mark of violence serves the purpose of drawing one's attention to an unknown trauma.

In the aftermath of the tragic explosion caused by Jacinto, Jaime finally speaks of Santi's murder. There is a flashback to the cistern room as Jaime verbally revisits the scene of the crime: (1) Jaime comes out of hiding — after Jacinto pushes Santi into a pillar and wounds his head-and bends over Santi to touch his bleeding forehead, and (2) Jaime comes out of hiding again-after Jacinto weighs down Santi's body and throws it into the water-to crouch in front of the cistern and cry. The bomb falls out of the sky as Jaime leaves the murder scene and walks into the courtyard. Carlos and the viewer-through the testimony of the witness Jaime (visual and verbal) and the approach of the wounded phantom - have now returned to the scene of the crime and witnessed its occurrence. As such, the history of the trauma is no longer unknown. Armed with the knowledge of the traumatic, Carlos can approach Santi without fleeing, without aversion to his repulsive appearance, because he recognizes and hears the crying wound.

Carlos progresses from a reactive stance to a proactive one towards the phantom presence as he recognizes that the lack of justice must be filled with justice, the lack of empathy with emotion, and the absence of assistance with action, yet he does not act alone. Jaime also realizes that his fear must be replaced with courage, since no one will fight for him and the other orphans; they must fight for themselves. Jacinto, lured into the cistern room, initially laughs at the sight of little boys armed with 
skinny sticks, but his laughter is shortly converted to pain as Jaime takes the first shot, stabbing him underneath the arm. As the boys use superior numbers to their advantage, they continually pierce Jacinto's body with their sticks until he is close enough to be shoved into the cistern. Santi is now free to claim his justice, a death for a death. The children, standing in front of the water with their bloodied sticks, have revisited the place of trauma and assisted the phantom. Not only has Santi's traumatic history been resituated within the broader narrative of the orphans' stories, but justice has been restored to an environment devoid of it.

There is no happy ending or airtight resolution in the film, but there are necessary restitutions. There is no guarantee that the orphans make it to town or find the nurture and assistance they so desperately require, but they have survived by moving from the sidelines of the battle to its forefront in their decision to assist Santi. Although it may seem shocking to call Jacinto's death justice instead of murder, it is also an act that occurs in an environment of ultimate impunity, one in which there is no formal legal system and no surviving guardians to whom the orphans can appeal. Regardless of their response to the cry of the phantom child, they still would have had to resort to a defensive violence to survive Jacinto's brutality. In the film, the lines between justice and vengeance blur due to the exceptional circumstances existing in the orphanage; the orphans are given no other recourse than to meet violence with violence or be killed.

In addition to my proposition that Jaime's drawing in El espinazo be considered for its potential cathartic properties and its signaling of a hidden crime, I suggested that the archival children's drawings be viewed as artistic publicity for human rights. This would also identify the drawings as the representation of a reprehensible crime (forced disappearance) in addition to a call for intervention, both characteristics shared with the diegetic drawing and wounded phantom. It is possible that the concept of art as catharsis may also be relevant to the archival drawings, since the children who participated in the project were Puchulu de Drangosch's grandchildren (ranging in age from five to nine years old), all of whom had experienced the violence of forced disappearance and appropriation firsthand (Moyano 2016). ${ }^{12}$ However, because Moyano indicated that the children were asked to draw pictures about the situation in Argentina, the work of catharsis, if applicable, and human rights are performed simultaneously. Whatever their function or purpose, the archival drawings also demand an accounting in their display of intolerable images reinforced by a naming of the individuals missing.

Of the eight, six of the illustrated postcards were connected to demands to know the whereabouts of "kidnapped" (forcibly disappeared or missing) children and two were tied to "kidnapped" pregnant women. The text on the backs of all eight begins with the phrase, "Con todo respeto, pero con todo dolor, queremos saber" ['With all due respect, but with much sorrow, we want to know'], which is then followed by one of two questions. For the postcards concerning "kidnapped" children, the demand is typed in all capital letters and reads, "DONDE ESTAN LOS NINOS SECUESTRADOS POR EL GOBIERNO ARGENTINO" ['Where are the children kidnapped by the Argentine government']. For those postcards referring to "kidnapped" pregnant women, the demand reads, "DONDE ESTAN LAS MUJERES EMBARAZADAS SECUESTRADAS POR EL GOBIERNO ARGENTINO” ['Where are the pregnant women kidnapped by the Argentine government']. The demand is then reiterated in Dutch and followed by a list of three names on each postcard with either the ages of the children/adolescents or the number of months the women were pregnant. In both cases, the emphasis is on the children/adolescents and fetuses, a focus evident in the children's drawings. ${ }^{13}$

In her analysis of Felman and Laub's seminal work on the Holocaust (Felman and Laub 1992), Kelly Oliver describes the necessity of bearing witness from the inside (declared impossible when the addressable other is abolished, as occurred in concentration camps) to the re-establishment of

12 The child artists were Moyano, her sisters, and cousin.

13 Several supporting entities are also listed: CO. SO. FAM. (COSOFAM), A.F.U.D.E., Nederlandse Kinderraad [Netherlands Council for Children], Komitee Twee [Committee Two], Kerk en Vrede [Church and Peace], I.F.O.R., Stichting Oecumenische Hulp [Foundation for Ecumenical Assistance], Kerken en Vluchtelingen [Churches and Refugees], and N.C.O., respectively. 
subjectivity (Oliver 2001). In turn, witnessing and subjectivity are connected to justice and require another person (who will respond and be responsible) to claim it:

Yet in order to reestablish subjectivity and in order to demand justice, it is necessary to bear witness to the inarticulate experience of the inside. ... It is the tension between finite understanding linked to historical facts and historically determined subject positions, and the infinite encounter linked to psychoanalysis and the infinite responsibility of subjectivity that produces a sense of agency. Such an encounter necessarily takes us beyond recognition and brings with it ethical obligation. (Oliver 2001, p. 90).

The children's drawings have the power of expressing the inexpressible (to bear witness to the inarticulate experience of the inside) - connected to subjectivity (requires the possibility of a witness for Oliver), response-ability, ethical obligations, and justice. For Oliver, "Response-ability is never solitary" (p. 91) (unlike the traumatic narrative addressed to no one). The drawings, when viewed as symbolic expressions of "the inside," request and require an audience who will be ethically responsible.

Building on Dori Laub's idea of an "inner witness" or addressable other, Oliver postulates:

To conceive of oneself as a subject is to have the ability to address oneself to another, real or imaginary, actual or potential. Subjectivity is the result of, and depends on, the process of witnessing-address-ability and response-ability. Oppression, domination, enslavement, and torture work to undermine and destroy the ability to respond and there-by undermine and destroy subjectivity. (Oliver 2001, p. 17).

In this context, the drawings can function as a means for children to address themselves to others and for human rights organizations through children to work against the forces of violence-the annihilation of social relations and of existence itself. Feierstein (2014) speaks of disappearance as more than murder in that it is an obliteration of one's existence. As a means of resisting the obliteration of the Other and as a reclamation of existence, the drawings attest to a violence that "disappeared" people. They are a tool employed to counteract the process of annihilation and re-establish subjectivity through a confirmation of address-ability and response-ability by "bear[ing] witness to the inarticulate experience of the inside" (Oliver 2001, p. 90).

If civilizing discourses are really discourses of exclusion, a making invisible of those in plain sight, then the dictatorship took this a step further by attempting to render invisible non-conforming citizens, conveniently labeled subversives (rendering them non-citizens and thus without the Rights guaranteed citizens by their government), through their "disappearance" (an initial Othering of people that later develops in certain places into forcibly disappearing the Othered). Arendt analyzed the contradiction inherent in barbarous acts that arise and are sustained by the ubiquitous spread of civilization and argued that "only with a completely organized humanity could the loss of home and political status become identical with expulsion from humanity altogether" (Arendt 1958, p. 297). The reorganizing discourse (el proceso de reorganización nacional or the National Reorganization Process) of the dictatorship, bolstered by the underlying civilizing discourse of the Nation, created categorizations or artificial boundaries as a means of isolating and Othering, a process that facilitated genocide as social practice.

Feierstein propagates a model that views "genocide not only as a latent potential of modernity but as [what he terms] a specific technology of power." For Feierstein, "A technology of power is a form of social engineering that creates, destroys, or reorganizes relationships within a given society." $\mathrm{He}$ postulates, "It influences the ways in which different social groups construct their identity, the identity of others, and the otherness of the Other, thus shaping the way that groups can relate to themselves and to one another" (Feierstein 2014, p. 1). By closely tying together genocide and social reorganization, genocide (in addition to its legal definition) emerges as a social practice in historical and sociological discourses (Feierstein 2014, p. 14). To push for the adoption of the Genocide Convention, Raphael Lemkin, who coined the word genocide, allowed for the exclusion of political groups, an exclusion that has now problematized the prosecuting of genocide in cases where persecution is tied to political groups or "doing" instead of existential reasons or "being" (Feierstein 2014, p. 32). 
The drawings have the potential to fight against the trivialization and normalization of violence by reminding those in positions of power that even children had witnessed Argentine state-sponsored violence, and they had not forgotten it. During the military dictatorship, many of these facts were known and not known (such as the existence of camps) by an Argentine populace paralyzed by fear, and so it was important to continually point to crimes the State was still in the process of concealing. ${ }^{14}$ Pilar Calveiro states, "Los militares habían hecho un gran esfuerzo por ocultar o hacer desaparecer los restos de sus víctimas. No sólo habían desaparecido a las personas sino que después desaparecieron a los desaparecidos" ['The military had made a great effort to hide or make the remains of their victims disappear. Not only had they made people disappear but, afterwards, they disappeared the forcibly disappeared'] (Calveiro 1998, p. 163). Drawings, in this case, testify to a violence that sought to annihilate by further disappearing already disappeared lives and bodies. They are a powerful reminder that the children/adolescents and women forcibly disappeared in Argentina might be out of sight, but they are certainly not out of mind/memory. Their names are known, and their traumatic pasts demand restitution.

\section{Concluding Thoughts on Fiction and the Archive}

As mentioned earlier, Jaime's drawing assists Carlos in uncovering Santi's violent death. Santi's body had been pushed into a cistern by Jacinto, effectively hiding or disappearing the murdered boy in the murky water. The drawing thus serves a cathartic purpose by creating a way for Jaime to revisit the site of Santi's death, of which he had not yet spoken, while also pointing to the murder victim. The drawing is Jaime's initial voiceless testimony (from or of the inside), seen in secret by Carlos (who witnesses from the outside). As is evident in El espinazo and the archival drawings, children draw what they see. The drawings visually speak for the victims in that they unveil the unseen and unresolved traumas of the past. As postulated, this uncovering of the past allows for restitution to occur as the isolated trauma is again situated within a chain of events and narrative:

$$
\begin{gathered}
\text { child artists } \leftrightarrow \text { phantoms/hauntings } \leftrightarrow \text { unknown trauma } \\
\downarrow \\
\uparrow \\
\text { (diegetic \& archival) drawings } \rightarrow
\end{gathered}
$$

The idea of haunting as a means of revealing past violence with the clear intent of pursuing justice is particularly evident in El espinazo, where Jaime's drawing becomes a tool for natural law that works in tandem with the supernatural (in the absence of positive laws). As the orphans answer the phantom's cry for justice, their bodies, repositories marked by violence, carry traumatic memory forward to a final reckoning in which the traumatized child's body is also the weapon or force that claims justice. With the archival children's drawings, the use of visual recreations of unresolved past violence is also utilized for the pursuit of a just recognition of wrongs committed, although within the framework of positive law and human rights work in exile. The archival drawings, as a call for response-ability and address-ability, pursue justice through COSOFAM's propagation of interventionist strategies (using children's drawings to expose violence and request intervention) and demand for accountability on the part of the Argentine State for the "missing" bodies connected to the names listed on the postcards. I have not currently located a document at the Archive stating that any action was taken on the part of the judge in question, but it is possible that a record exists. This would be an intriguing line of inquiry for future studies.

In conclusion, in both fiction and the archive, children actively unveil past violence and demand an accounting. Their drawings "show" the crime. Children become the bearers and transmitters of traumatic memory through hauntings, wounds, and/or drawings. This does not mean that children

14 See also, Marguerite Feitlowitz. 2011. A Lexicon of Terror: Argentina and the Legacies of Torture, Revised and Updated with a new Epilogue. Oxford: Oxford University Press. 
as the portents of justice must also mete out justice, but in del Toro's film, they do. The weakest and most oppressed victims-orphan children trapped in a state of exception and affected by extreme violence-become agents of restitution and justice, just as Argentine children in exile in the Netherlands actively participated in the fight against state repression by bearing witness of the inside- both acts serving as reminders that "response-ability is never solitary" (Oliver 2001, p. 91).

Acknowledgments: I acknowledge funding I received to do research in Argentina, where I discovered the archival drawings, in footnote 2. I received the Ben and Rue Pine travel grant (summer of 2015).

Conflicts of Interest: The author declares no conflict of interest.

\section{References}

Alicia Raquel Puchulu de Drangosch Archive. Donated 2014. Comisión de Solidaridad con Familiares de Desaparecidos en Argentina (COSOFAM). Eight Postcards Imprinted with Children's Drawings. No date. Listed in the "Catálogo de Fondos Escritos/Audiovisuales/Fotográficos". Buenos Aires: Archivo Nacional de la Memoria, Accessed on 8 September 2015.

Arendt, Hannah. 1958. The Origins of Totalitarianism. Cleveland and New York: Meridian Books, The World Publishing Company.

Bergero, Adriana. 2010. Espectros, escalofríos y discursividad herida en El espinazo del diablo: El gótico como cuerpo-geografía cognitiva-emocional de quiebre. No todos los espectros permanecen abandonados. Project Muse 125: 433-56.

Calveiro, Pilar. 1998. Poder y Desaparición: Los Campos de Concentración en Argentina. Buenos Aires: Ediciones Colihue.

Calvo, A. 2016. Archivo Nacional de la Memoria. Email message to author, 7 January.

Caruth, Cathy. 1996. Unclaimed Experience: Trauma, Narrative, and History. Baltimore: The Johns Hopkins University Press.

El espinazo del diablo [The Devil's Backbone]. 2001. Directed by Toro Guillermo del. Production Companies: El Deseo S.A., Tequila Gang, and Anhelo Producciones. DVD.

Feierstein, Daniel. 2014. Genocide as Social Practice: Reorganizing Society under the Nazis and Argentina's Military Juntas. Translated by Douglas Andrew Town. New Brunswick, and London: Rutgers University Press.

Felman, Shoshana, and Dori Laub. 1992. Testimony: Crises of Witnessing in Literature, Psychoanalysis, and History. New York and London: Routledge.

Gardner, C. 2017. Light House Program at South Coast Hospice. Email message to author, 28 February.

Gatti, Gabriel. 2011. Identidades Desaparecidas: Peleas por el Sentido en los Mundos de la Desaparición Forzada. Buenos Aires: Prometeo Libros.

Lázaro-Reboll, Antonio. 2007. The Transnational Reception of El espinazo del diablo (Guillermo del Toro 2001). Hispanic Research Journal 8: 39-51. [CrossRef]

Moyano, E. 2016. Suarez del Archivo nacional de la memoria. Email message to author, 16 October.

Oliver, Kelly. 2001. Witnessing: Beyond Recognition. Minneapolis and London: University of Minnesota Press.

Ranciere, Jacques. 2009. The Emancipated Spectator. Translated by Gregory Elliott. London and New York: Verso.

Rocha, Carolina, and Georgia Seminet. 2012. Introduction. In Representing History, Class, and Gender in Spain and Latin America: Children and Adolescents in Film. Edited by Rocha, Carolina and Georgia Seminet. New York: Palgrave Macmillan, pp. 1-29.

Taylor, Diana. 2009. Cuerpos políticos/Body Politics. In Body Politics: Políticas del Cuerpo en la Fotografía Latinoamericana. Edited by Brodsky, Marcelo and Julio Pantoja. Buenos Aires: La marca editora, pp. 20-31.

Van der Kolk, Bessel A., and Onno van der Hart. 1995. The Intrusive Past: The Flexibility of Memory and the Engraving of Trauma. In Trauma: Explorations in Memory. Edited by Caruth, Cathy. Baltimore and London: The John Hopkins University Press, pp. 158-82.

(C) 2018 by the author. Licensee MDPI, Basel, Switzerland. This article is an open access article distributed under the terms and conditions of the Creative Commons Attribution (CC BY) license (http://creativecommons.org/licenses/by/4.0/). 